Article

\title{
Dimerized Domain V of Beta2-Glycoprotein I Is Sufficient to Upregulate Procoagulant Activity in PMA-Treated U937 Monocytes and Require Intact Residues in Two Phospholipid-Binding Loops
}

\author{
Alexey Kolyada, David A. Barrios and Natalia Beglova * \\ Department of Medicine, Beth Israel Deaconess Medical Center and Harvard Medical School, Boston, \\ MA 02215, USA; akolyada@yahoo.com (A.K.); dabarrio@bidmc.harvard.edu (D.A.B.) \\ * Correspondence: nbeglova@yahoo.com; Tel.: +1-617-735-4009 \\ Academic Editor: Ricard Cervera
}

Received: 23 December 2016; Accepted: 3 May 2017; Published: 2 June 2017

\begin{abstract}
Upregulation of the procoagulant activity of monocytes by antibodies to beta2-glycoprotein I ( $\beta 2 \mathrm{GPI})$ is one of the mechanisms contributing to thrombosis in antiphospholipid syndrome. Current knowledge about receptors responsible for the upregulation of procoagulant activity by $\beta 2 \mathrm{GPI} /$ anti- $\beta 2 \mathrm{GPI}$ complexes and their binding sites on $\beta 2 \mathrm{GPI}$ is far from complete. We quantified the procoagulant activity expressed by phorbol 12-myristate 13-acetate (PMA)-differentiated U937 cells by measuring clotting kinetics in human plasma exposed to stimulated cells. Cells stimulated with anti- $\beta 2$ GPI were compared to cells treated with dimerized domain V of $\beta 2$ GPI ( $\beta 2 G P I-D V)$ or point mutants of $\beta 2$ GPI-DV. We demonstrated that dimerized $\beta 2$ GPI-DV is sufficient to induce procoagulant activity in monocytes. Using site-directed mutagenesis, we determined that the phospholipid-binding interface on $\beta 2$ GPI is larger than previously thought and includes Lys308 in $\beta 2 \mathrm{GPI}-\mathrm{DV}$. Intact residues in two phospholipid-binding loops of $\beta 2 \mathrm{GPI}-\mathrm{DV}$ were important for the potentiation of procoagulant activity. We did not detect a correlation between the ability of $\beta 2 \mathrm{GPI}$-DV variants to bind ApoER2 and potentiation of the procoagulant activity of cells. The region on $\beta 2 \mathrm{GPI}$ inducing procoagulant activity in monocytes can now be narrowed down to $\beta 2 \mathrm{GPI}-\mathrm{DV}$. The ability of $\beta 2$ GPI-DV dimers to come close to cell membrane and attach to it is important for the stimulation of procoagulant activity.
\end{abstract}

Keywords: beta2-glycoprotein I; antiphospholipid syndrome; antiphospholipid antibodies; anticardiolipin antibody

\section{Introduction}

Antiphospholipid syndrome (APS) is an autoimmune disease characterized by clinical thrombosis, recurrent fetal loss during pregnancy and the presence of antiphospholipid antibodies [1,2]. Antiphospholipid antibodies (aPL) detected by laboratory tests for APS are highly heterogeneous even in a single patient $[3,4]$. The majority of aPL recognize serum proteins that bind anionic phospholipids. Autoantibodies that bind directly to anionic phospholipids are often present in diseases that do not have any link to thrombosis and are generally considered irrelevant to APS [5-7]. Nevertheless, it was recently demonstrated that APS patients may have antibodies that bind cardiolipin without serum protein cofactor, and these antibodies are prothrombotic in mice [8]. The heterogeneity of antiphospholipid antibodies and the wide range of clinical features in APS patients suggest that there are multiple pathways leading to the disease [9-11].

There is a wealth of data demonstrating that anti- $\beta 2$ GPI antibodies are common in APS patients and that these antibodies correlate with thrombosis [12-17]. Anti- $\beta 2$ GPI antibodies potentiate 
thrombus formation in animal models of thrombosis and induce a prothrombotic state in monocytes, platelets and endothelial cells in vitro [18-20]. B2GPI/anti- $\beta 2$ GPI complexes have been reported to interact with several receptors and cell-surface molecules, such as toll-like receptors TLR2, TLR4, TLR8, ApoER2, GPIb $\alpha$ and annexin A2 [21]. The involvement of TLR4, ApoER2 and annexin A2 in the prothrombotic effects of anti- $\beta 2$ GPI antibodies is supported by in vivo studies using murine thrombosis models [22-25]. The relative contribution of these receptors to cellular activation by anti- $\beta 2$ GPI antibodies and the onset of thrombosis in vivo remains poorly understood. It was recently demonstrated in monocytes that endocytosis is required for anti- $\beta 2$ GPI signaling [26].

B2GPI is a serum protein consisting of five domains [27]. Flexible linkers between domains permit the $\beta 2$ GPI molecule to adopt different shapes. The circular shape in which domain I is adjacent to domain $\mathrm{V}$ is the predominant conformation of $\beta 2 \mathrm{GPI}$ in normal human plasma. In the pathologically-active extended conformation of $\beta 2 \mathrm{GPI}$, domain $\mathrm{V}$ is independent of other $\beta 2 \mathrm{GPI}$ domains. Anti- $\beta 2$ GPI antibodies in APS patients with thrombosis most often bind to domain I of $\beta 2 \mathrm{GPI}$ [28]. Current knowledge of how $\beta 2 \mathrm{GPI} /$ antibody complexes interact with receptors is incomplete. It is limited to ApoER2, GPIb $\alpha$ and anionic phospholipids. The binding sites for these receptors were localized to domain $V$ of $\beta 2 G P I$ [29-34].

Induction of tissue factor (TF) in endothelial cells and monocytes is an important prothrombotic mechanism of $\beta 2$ GPI/anti- $\beta 2$ GPI complexes [35-37]. Monocytes isolated from APS patients have elevated expression of TF and TF-dependent procoagulant activity [38-40]. The ability of patients' IgG to stimulate TF activity in monocytes in vitro correlates with the presence of clinical thrombosis and the levels of anti- $\beta 2$ GPI antibodies in IgG samples [41]. Experimental data implicate TLR2, TLR4, ApoER2 and annexin A2 in the upregulation of TF by anti- $\beta 2$ GPI antibodies [23,42-44]. The binding site on $\beta 2$ GPI for the receptor responsible for the induction of procoagulant activity is unknown. Indefinite anticoagulation, which is a treatment of choice for high risk APS patients, is not always effective in preventing the recurrence of thrombosis [45-47]. A detailed understanding of how $\beta 2$ GPI interacts with receptors involved in cellular activation by $\beta 2 \mathrm{GPI} /$ anti- $\beta 2 \mathrm{GPI}$ complexes is essential for the development of drugs specific for antiphospholipid syndrome.

In this study, we compared dimerized $\beta 2$ GPI-DV to $\beta 2$ GPI/anti- $\beta 2$ GPI complexes by its ability to stimulate procoagulant activity in phorbol 12-myristate 13-acetate (PMA)-differentiated U937 cells. U937 is a monocytic cell line, where cells are arrested at an early stage of differentiation. Treatment with PMA induces differentiation of U937 cells to monocytes/macrophages characterized by expression of CD14 and CD11a, CD11b and CD18 integrins [48]. U937 monocytes express all receptors that were suggested to interact with $\beta 2$ GPI/anti- $\beta 2$ GPI complexes [49-52] and respond to antibodies isolated from APS patients with thrombosis by upregulating TF [41]. We used site-directed mutagenesis to change residues in $\beta 2$ GPI-DV involved in binding to ApoER2 and anionic phospholipids and compared how these mutations affected the induction of procoagulant activity expressed by PMA-differentiated U937 cells.

\section{Results}

2.1. In the Presence of Dimerizing Antibodies, Domain V of $\beta 2 G P I$ Is Sufficient to Stimulate the Procoagulant Activity of PMA-Differentiated U937 Monocytes

To mimic dimerized domain $V$ in $\beta 2$ GPI/anti- $\beta 2$ GPI complexes, we attached an HA-tag (amino acid sequence YPYDVPDYA) at the N-terminus of domain $\mathrm{V}$ and used anti-HA-tag antibodies to form HA-DV dimers. The procoagulant activity induced by HA-DV/anti-HA complexes in U937 cells was compared to that induced by $\beta 2 \mathrm{GPI} /$ anti- $\beta 2 \mathrm{GPI}$ complexes (Figure 1A,B). The procoagulant activity was quantified using coagulation kinetics curves (Figure 1B). Each experimental condition was characterized by the time required to achieve half-maximal coagulation. In our preliminary studies, we performed dose response experiments to determine the concentrations of anti- $\beta 2 \mathrm{GPI}$ and anti-HA antibodies that are necessary to induce the same level of procoagulant activity in cells as the procoagulant activity induced by $1 \mu \mathrm{g} / \mathrm{mL}$ of LPS. We found the needed concentrations to 
be approximately $100 \mathrm{nM}$, which is what we used in our studies. The concentrations of $\beta 2 \mathrm{GPI}$ and HA-DV $(\sim 0.4 \mu \mathrm{M}$ of $\beta 2 \mathrm{GPI}$ in $10 \%$ serum and $0.8 \mu \mathrm{M}$ of HA-DV) were in excess of the concentrations of anti- $\beta 2$ GPI and anti-HA antibodies used, so that antibodies were fully loaded with the antigen.
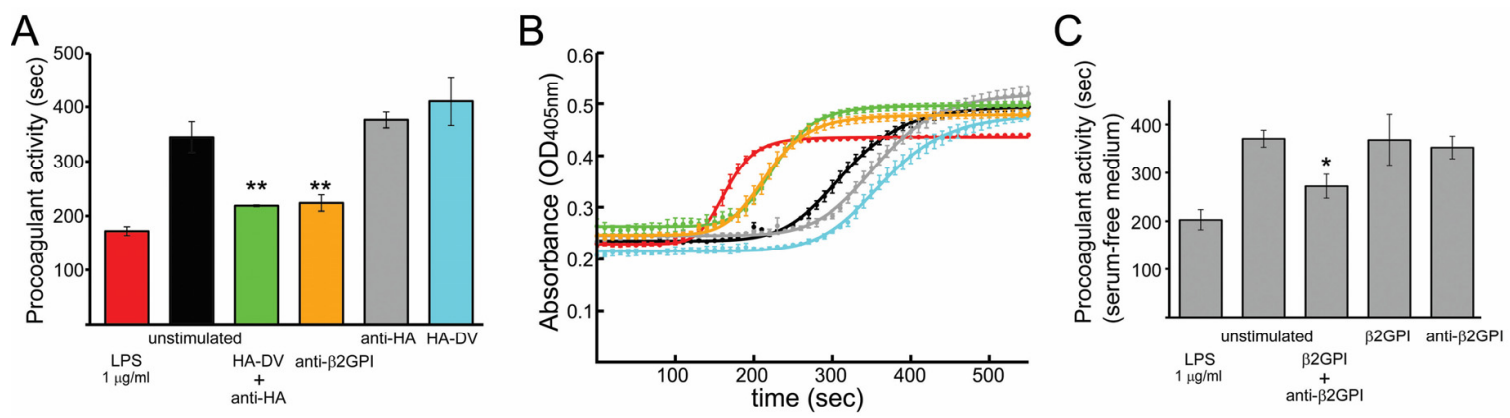

Figure 1. Procoagulant activity induced in U937 cells. (A) Cell culture medium contained 10\% normal human serum, which was a source of $\beta 2$ GPI. PMA-treated U937 cells were incubated for $6 \mathrm{~h}$ with LPS $(1 \mu \mathrm{g} / \mathrm{mL})$; medium; HA-DV $(8 \mu \mathrm{g} / \mathrm{mL})$ with anti-HA $(14 \mu \mathrm{g} / \mathrm{mL})$; anti- $\beta 2 \mathrm{GPI}(16 \mu \mathrm{g} / \mathrm{mL})$; anti-HA $(14 \mu \mathrm{g} / \mathrm{mL})$ alone; and HA-DV $(8 \mu \mathrm{g} / \mathrm{mL})$ alone. ${ }^{* *} p<0.001$ compared to medium, HA-DV only and anti-HA only; (B) Example of coagulation kinetics curves measured in one of the three experiments used to quantify procoagulant activity in (A). From left to right are the kinetics curves corresponding to cells treated with LPS (red); HA-DV with anti-HA (green); anti- $32 \mathrm{GPI}$ (orange); medium (black); anti-HA alone (gray); and HA-DV alone (cyan). Each data point represents the mean and the deviation from the mean of measurements performed in duplicates; (C) Procoagulant activity induced by anti- $\beta 2$ GPI in serum-free medium depends on the presence of $\beta 2$ GPI. PMA-treated U937 cells were incubated for $6 \mathrm{~h}$ in serum-free medium supplemented with LPS $(1 \mu \mathrm{g} / \mathrm{mL})$; medium; $\beta 2 \mathrm{GPI}$ $(20 \mu \mathrm{g} / \mathrm{mL})$ with anti- $\beta 2 \mathrm{GPI}(16 \mu \mathrm{g} / \mathrm{mL}) ; \beta 2 \mathrm{GPI}(20 \mu \mathrm{g} / \mathrm{mL})$ alone; and anti- $\beta 2 \mathrm{GPI}(16 \mu \mathrm{g} / \mathrm{mL})$ alone. $* p<0.05$ compared to medium and $\beta 2$ GPI alone. Procoagulant activities in $(A, C)$ were quantified from coagulation kinetics curves and expressed as time to half-maximal coagulation. Values represent mean $\pm \mathrm{SD}(n=3)$.

Normal human plasma exposed to cells treated with anti-ß2GPI or anti-HA-tag antibodies in the presence of HA-DV coagulated significantly faster than plasma exposed to untreated cells (Figure 1A). Treating cells with either HA-DV alone or anti-HA antibodies alone did not change coagulation time compared to untreated cells. The acceleration of coagulation by monocytes stimulated with anti- $\beta 2 \mathrm{GPI}$ antibodies was $\beta 2$ GPI dependent (Figure 1C). When cells were stimulated under serum-free conditions, only cells exposed to both $\beta 2$ GPI and anti- $\beta 2$ GPI antibodies significantly accelerated coagulation compared to untreated cells. Neither anti- $\beta 2$ GPI antibodies nor $\beta 2$ GPI alone had any effect on coagulation time in a serum-free medium.

\subsection{Measured Procoagulant Activity of U937 Cells Is TF-Dependent}

The coagulation cascade consists of two pathways leading to the formation of the fibrin clot: the intrinsic and extrinsic pathways. The intrinsic clotting pathway is activated by the contact activation of FXII, and the extrinsic clotting pathway is initiated by the TF/FVIIa complex. To differentiate the contribution of FXII-dependent and TF-dependent pathways to the initiation of the measured procoagulant activity of the treated U937 cells, we used plasmas deficient in factors FVII, FXII and FXI. Deficient plasmas were exposed to U937 cells stimulated for $6 \mathrm{~h}$ with test reagents. The coagulation kinetics of deficient plasmas were compared to the coagulation kinetics of normal plasma (Figure 2). For all stimulants (LPS, HA-DV/anti-HA complexes, anti- $\beta 2$ GPI and untreated cells), factor FVII-deficient plasma exposed to stimulated cells clotted significantly more slowly than normal plasma. The absence of factors FXI or FXII had no effect on the clotting kinetics, when compared to the clotting kinetics of normal plasma. These results demonstrated that the TF/FVIIa complex formed on the surface of U937 cells was the major activator of the clotting cascade in our experiments. Therefore, our assay detects 
the procoagulant activity of cell-surface TF, which is upregulated by the treatment with anti- $\beta 2 \mathrm{GPI}$ antibodies and with dimerized $\beta 2$ GPI-DV (Figure 1A).

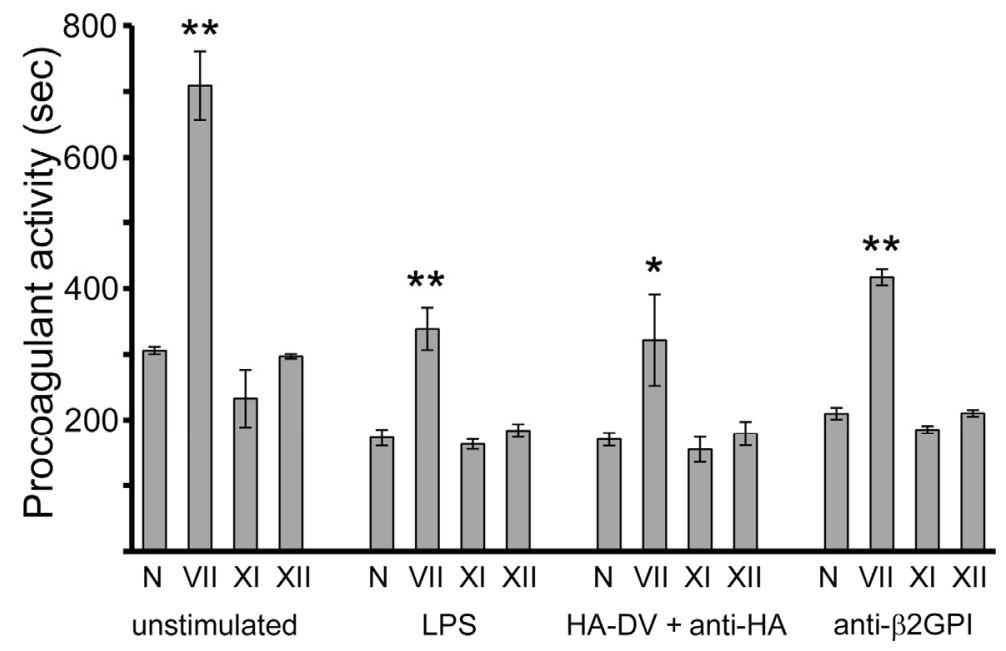

Figure 2. Procoagulant activity exhibited by U937 cells is caused by the upregulation of cell-surface tissue factor. Cell culture medium contained 10\% normal human serum. PMA-treated U937 cells were stimulated for $6 \mathrm{~h}$ with medium only; LPS $(1 \mu \mathrm{g} / \mathrm{mL})$; HA-DV $(8 \mu \mathrm{g} / \mathrm{mL})$ with anti-HA $(14 \mu \mathrm{g} / \mathrm{mL})$; and anti- $\beta 2 \mathrm{GPI}(16 \mu \mathrm{g} / \mathrm{mL})$. The procoagulant activities of the cells were measured in pooled normal human plasma (N), as well as in plasmas deficient in factors VII, XI and XII. ${ }^{* *} p<0.001,{ }^{*} p<0.01$, compared to normal plasma.

\subsection{TNF $\alpha$ Released by U937 Cells Stimulated with either HA-DV/Anti-HA Complexes or Anti- $\beta 2$ GPI} Antibodies Was Negligible Compared to TNFa Released by Cells Stimulated with TLR4 and TLR2 Ligands

We measured the amount of TNF $\alpha$ released by cells stimulated with either anti- $\beta 2 \mathrm{GPI}$ antibodies or HA-DV / anti-HA complexes and compared it to the amounts of TNF $\alpha$ secreted by cells stimulated with the TLR4-specific ligand LPS and the TLR2-specific ligand Pam3CSK4 (Figure 3A-D). LPS and Pam3CSK4 upregulated procoagulant activity and induced a massive release of TNF $\alpha$ from U937 cells (Figure 3C,D). Interestingly, although the procoagulant activity induced by anti- $\beta 2 \mathrm{GPI}$ antibodies and by HA-DV/anti-HA complexes was similar to that induced by LPS, neither anti- $\beta 2$ GPI antibodies nor HA-DV / anti-HA complexes induced appreciable release of TNF $\alpha$ from U937 cells.

\subsection{Design and Characterization of Point Mutants of Domain V of $\beta 2 G P I(H A-D V)$}

Information, detailed at the amino acid resolution, on how $\beta 2$ GPI interacts with cells is limited to ApoER2 and anionic phospholipids [29,30,32,34,53]. Domain V of $\beta 2 \mathrm{GPI}$ contains residues critical for the binding to ApoER2 and anionic phospholipids (Figure 4). U937 cells express two isoforms of ApoER2 [52], each of which contains the $\beta 2$ GPI-binding module A1 in the ligand-binding domain [54]. We made point mutants of the HA-tagged domain V of $\beta 2$ GPI (HA-DV) with the goal of dissecting the contribution of ApoER2 and anionic phospholipids to potentiation of procoagulant activity in monocytes treated with dimerized HA-DV. The selected residues were Lys308 and Lys282, which are involved in the binding of $\beta 2$ GPI domain V to ApoER2 [34,53] and the residues in two phospholipid-binding loops (Figure 4). One of the phospholipid-binding loops contains basic residues Lys284, Lys286 and Lys287, and the other loop is composed of a hydrophobic sequence between the residues Leu313 and Trp316 [29,30,32]. 

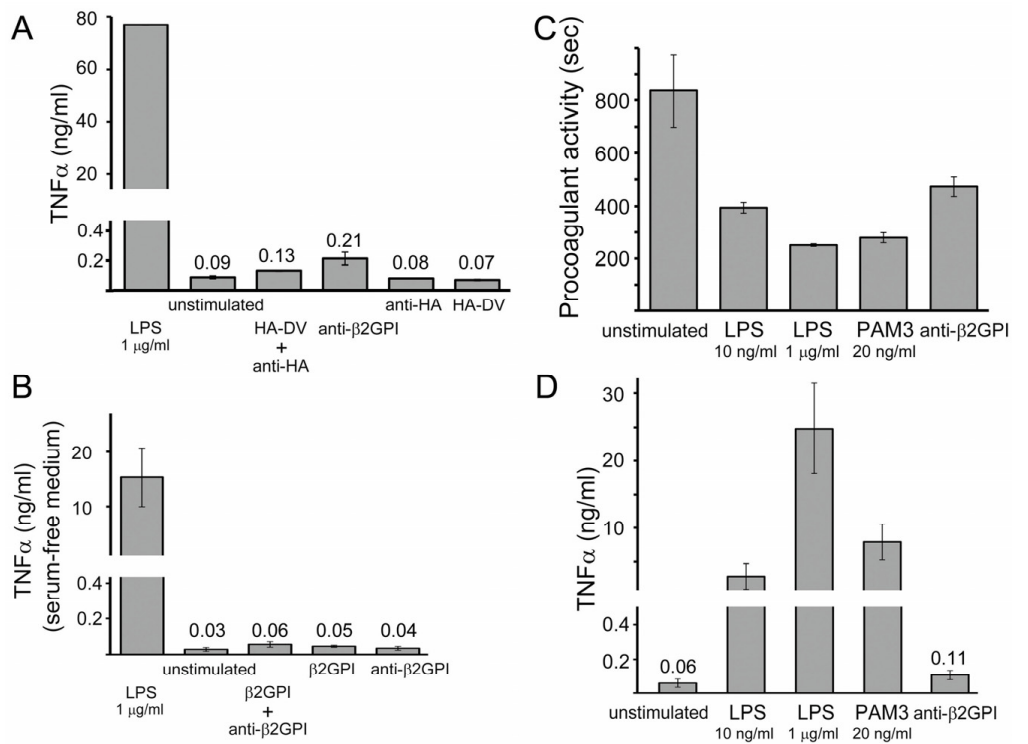

Figure 3. TNF $\alpha$ released into the medium from U937 cells. (A) Cell culture medium contained 10\% normal human serum. PMA-treated U937 cells were incubated for $6 \mathrm{~h}$ with LPS $(1 \mu \mathrm{g} / \mathrm{mL})$; medium; HA-DV $(8 \mu \mathrm{g} / \mathrm{mL})$ with anti-HA $(14 \mu \mathrm{g} / \mathrm{mL})$; anti- $\beta 2 \mathrm{GPI}(16 \mu \mathrm{g} / \mathrm{mL}) ;$ anti-HA $(14 \mu \mathrm{g} / \mathrm{mL})$ alone; and HA-DV $(8 \mu \mathrm{g} / \mathrm{mL})$ alone; (B) PMA-treated U937 cells were incubated for $6 \mathrm{~h}$ in a serum-free medium supplemented with LPS $(1 \mu \mathrm{g} / \mathrm{mL})$; medium; $\beta 2 \mathrm{GPI}(20 \mu \mathrm{g} / \mathrm{mL})$ with anti- $\beta 2 \mathrm{GPI}(16 \mu \mathrm{g} / \mathrm{mL})$; $\beta 2 \mathrm{GPI}(20 \mu \mathrm{g} / \mathrm{mL})$ alone; and anti- $\beta 2 \mathrm{GPI}(16 \mu \mathrm{g} / \mathrm{mL})$ alone. Values represent mean $\pm \mathrm{SD}(n=3)$; $(C, D)$ Procoagulant activities (C) and TNF $\alpha$ released into the medium (D). PMA-treated U937 cells were incubated for $6 \mathrm{~h}$ with medium; LPS (10 ng/mL); LPS (1 $\mu \mathrm{g} / \mathrm{mL}) ;$ Pam3CSK4 $(20 \mathrm{ng} / \mathrm{mL})$; and anti- $\beta 2 \mathrm{GPI}(16 \mu \mathrm{g} / \mathrm{mL})$. Results are expressed as the mean \pm deviation from the mean $(n=2)$. Mean value of released TNF $\alpha$ is specified at the top of a column.

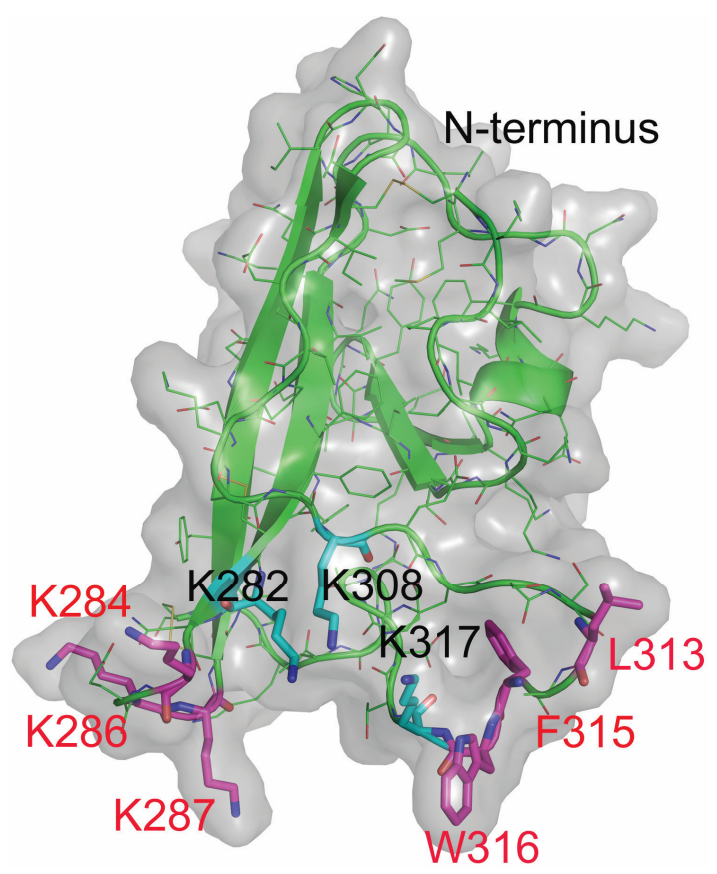

Figure 4. Structure of domain V of $\beta 2 \mathrm{GPI}$ (cartoon representation). The transparent molecular surface of domain $\mathrm{V}$ of $\beta 2 \mathrm{GPI}$ is colored gray. The residues interacting with A1 (K308, K317 and K282, colored cyan) and the residues in two phospholipid-binding loops (K284, K286, K287 and L313, F315, W316, colored magenta) are rendered as sticks. 


\subsubsection{The Binding of HA-DV Variants to ApoER2}

A1 is a polypeptide that closely resembles the $\beta 2$ GPI-binding module from ApoER2 [53,54]. The ability of HA-DV variants to bind ApoER2 was evaluated by comparing their ability to bind A1. The binding affinity between HA-DV variants and A1 was evaluated by isothermal titration calorimetry (ITC) (Figure 5). ITC is used to directly measure the heat released or absorbed, when binding occurs. HA-DV or HA-DV variants were placed in a sample cell and titrated with A1. Heat changes were detected and measured. First, we measured the binding curve and calculated the binding constant for the HA-DV / A1 complex. We then used the same experimental conditions to compare HA-DV variants to HA-DV with respect to their ability to bind A1. The quantity of heat released upon binding, which is measured by ITC, is directly proportional to the amount of binding. We compared titration curves measured for HA-DV mutants to the titration curve measured for HA-DV. Four mutants of HA-DV bound A1 with affinity similar to that of wild type HA-DV. These were the two HA-DV variants with conservative Lys to Arg mutations (Lys308/Arg and Lys282/Arg) and the two HA-DV variants with mutations in one of the two phospholipid-binding loops (Leu313/Asn and Leu313/Asp_Phe315/Ser). The shallow slope of titration curves measured for all other studied mutations in HA-DV strongly suggests that these mutations disrupted the binding of HA-DV mutants to A1. These results confirmed our previous observations that the hydrophobic loop Leu313-Phe315 is far from the binding interface in the HA-DV / A1 complex [34,53].
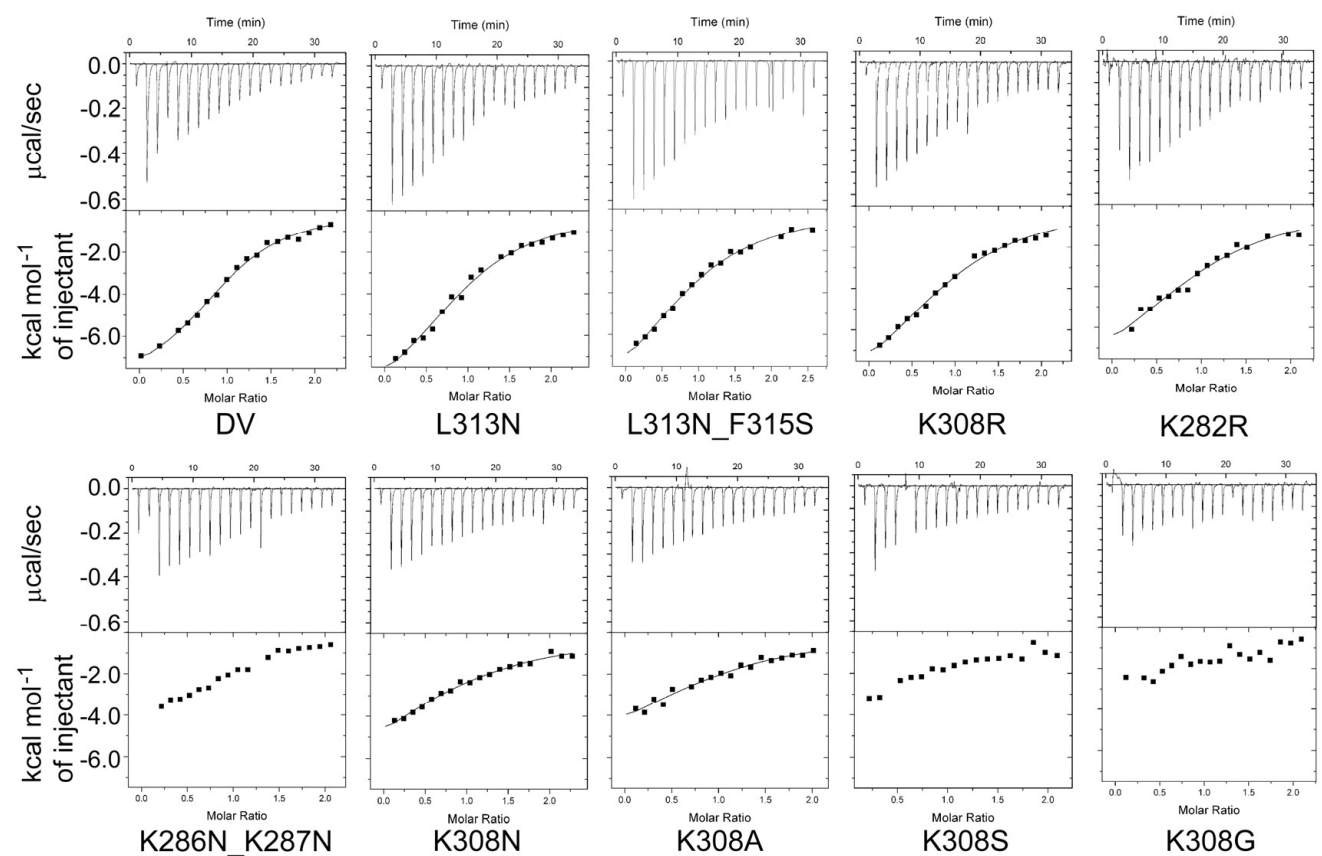

$\mathrm{K} 282 \mathrm{R}$
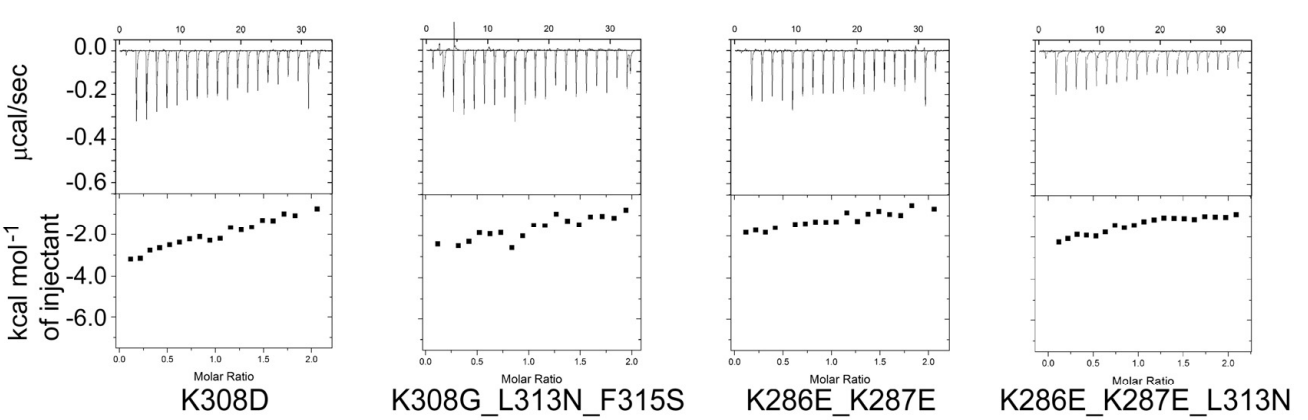

Figure 5. Binding of A1 to HA-DV variants. Isothermal titration calorimetry (ITC) titrations of HA-DV variants $(50 \mu \mathrm{M})$ in a sample cell with $\mathrm{A} 1(500 \mu \mathrm{M})$ in the injection syringe. 


\subsubsection{The Binding of HA-DV Variants to Cardiolipin}

Next, we analyzed the ability of HA-DV mutants to bind the anionic phospholipid cardiolipin compared to wild type HA-DV. Half-maximal binding to cardiolipin was achieved at a $1.2 \mu \mathrm{M}$ concentration of wild type HA-DV (Figure 6A). From the cardiolipin-binding curve measured for wild type HA-DV, we selected two concentrations, $500 \mathrm{nM}$ and $1000 \mathrm{nM}$, which fall in the linear region of the binding curve. The cardiolipin binding ability of HA-DV variants was compared to HA-DV at protein concentrations of $500 \mathrm{nM}$ and $1000 \mathrm{nM}$ (Figure 6B). Only the Lys308/Arg and Lys282/Arg variants of HA-DV retained cardiolipin binding activity similar to that of wild type HA-DV (Figure 6B). Any other residue besides Arg in place of Lys308 dramatically reduced the cardiolipin binding of mutated HA-DV, strongly suggesting that Lys308 is part of the phospholipid-binding interface on $\beta 2$ GPI. Mutations in either of the two phospholipid-binding loops disrupted the binding of HA-DV mutants to cardiolipin, as expected. Three mutants (Lys286/Glu_Lys287/Glu, Lys286/Glu_Lys287/Glu_Leu313/Asn and Lys308/Gly_Leu313/Asn_Phe315/Ser) retained less than 4\% of cardiolipin-binding activity compared to wild type HA-DV.

\subsection{ApoER2 Does Not Contribute to Upregulation of Procoagulant Activity in U937 Cells}

We evaluated how point mutations in domain $\mathrm{V}$ affected the ability of HA-DV dimers to stimulate procoagulant activity in U937 cells. As illustrated by Figure 6C, HA-DV variants can be divided into three groups based on their ability to induce procoagulant activity in cells stimulated in the presence of dimerizing anti-HA antibodies. These are (Group 1) HA-DV variants that stimulated cells like wild type HA-DV (the difference in procoagulant activity between unstimulated cells and cells stimulated with HA-DV variants was statistically significant), (Group 2) HA-DV variants that induced procoagulant activity similar to that exhibited by unstimulated cells (the difference in procoagulant activity induced in cells stimulated with wild type HA-DV and cells stimulated with HA-DV variants was statistically significant) and (Group 3) intermediate HA-DV variants, whose activity in cells was not statistically different from either untreated cells or cells stimulated with wild type HA-DV. In the absence of dimerizing anti-HA antibodies, neither of the HA-DV mutants induced procoagulant activity statistically different from procoagulant activity exhibited by unstimulated cells, as we have already demonstrated previously.

HA-DV variants that retained their ability to bind A1 and, therefore, were capable of interacting with ApoER2 (hatched columns on Figure 6C) were distributed among all three groups of HA-DV variants. This result suggests that the binding of HA-DV/anti-HA complexes to ApoER2 is not important for the induction of procoagulant activity in U937 cells.

\subsection{Intact Residues in the Two Phospholipid-Binding Loops of HA-DV Are Important for the Ability of HA-DV/Anti-HA Complexes to Induce Procoagulant Activity in U937 Cells}

The pathological function of $\beta 2 \mathrm{GPI}$ is a result of both dimerization of two $\beta 2 \mathrm{GPI}$ molecules by antibodies and functional interactions with receptors and phospholipids. In our system, the binding of antibodies to the epitope tag creates HA-DV/anti-HA complexes in solution, allowing us to focus on the functional interactions.

It is clear from Figure 6C that mutation in either of the two phospholipid-binding loops in HA-DV resulted in a dimer that does not upregulate procoagulant activity of U937 cells. The ability of mutants to come close to the cell membrane and bind to it, at least to some extent, is important for stimulating the procoagulant activity. Three out of the five mutants that failed to stimulate procoagulant activity (Group 2, Figure 6C) have charge reversal mutations. All five mutants retained less than $20 \%$ of the cardiolipin-binding ability of wild type HA-DV, and three of these mutants (gray columns on Figure $6 \mathrm{C}$ ) retained less than $4 \%$ of the cardiolipin binding. 
A
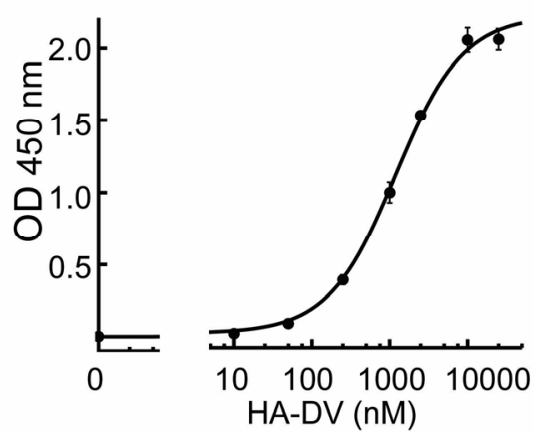

B

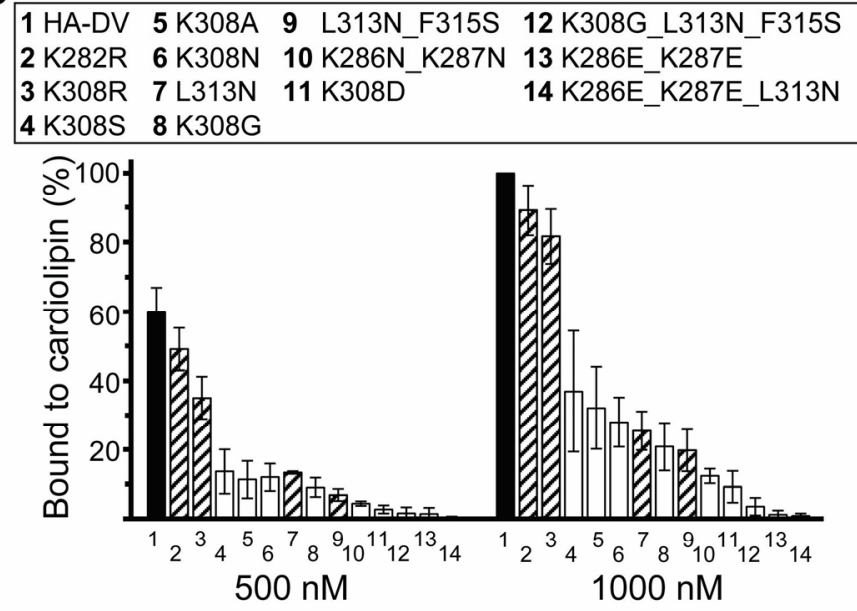

C

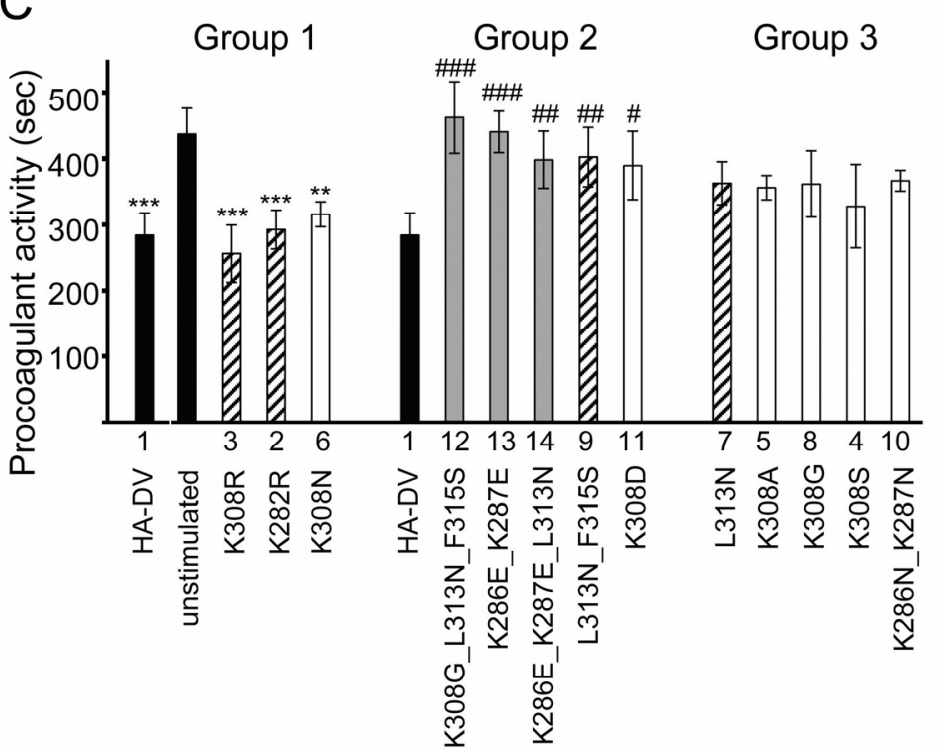

D

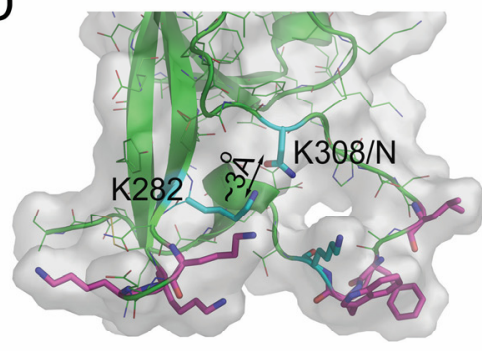

Figure 6. The ability of HA-DV variants to bind cardiolipin and induce procoagulant activity in U937 cells. (A) The binding of wild type HA-DV to cardiolipin. The half-maximal binding was achieved at $1.2 \mu \mathrm{M}$ of HA-DV. Each data point shows the mean \pm deviation from the mean of two measurements; (B) The ability of HA-DV variants to bind cardiolipin compared to wild type HA-DV (black columns). HA-DV variants that bind A1 are designated by hatched columns. Results are expressed as the percentage of cardiolipin binding measured for wild type HA-DV at $1000 \mathrm{nM}$. Values represent the mean $\pm \mathrm{SD}(n=3)$. HA-DV mutants are numbered as in $(\mathbf{C})$; (C) Procoagulant activity in cells treated with HA-DV variants $(8 \mu \mathrm{g} / \mathrm{mL})$ in the presence of anti-HA $(14 \mu \mathrm{g} / \mathrm{mL}){ }^{* * *} p<0.001$ and ${ }^{* *} p<0.01$ compared to medium. ${ }^{\# \#} p<0.001,{ }^{\# \#} p<0.01$ and ${ }^{\#} p<0.05$ compared to wild type HA-DV in the presence of anti-HA. HA-DV variants are numbered as in (B). HA-DV variants that bind A1 (hatched columns). HA-DV variants that have less than $4 \%$ of cardiolipin binding (gray columns). Values represent the mean $\pm \mathrm{SD}(n=3)$; (D) Putative hydrogen bond formed between the sidechains of residues K282 and N308 in the K308/N mutant of HA-DV. The transparent molecular surface of domain V of $\beta 2 \mathrm{GPI}$ is colored gray. Sidechains interacting with A1 (cyan) and with phospholipids (magenta) are rendered as sticks.

Three of the studied mutants, Lys308/Arg, Lys282/Arg and Lys308/Asn, were as good as wild type HA-DV in stimulating the procoagulant activity in U937 cells (Group 1, Figure 6C). A conservative Lys to Arg mutation often has little effect on protein function explaining why Lys308/Arg and 
Lys282/Arg mutants closely resemble wild type HA-DV in stimulating procoagulant activity. On the other hand, the Lys308/Asn mutant showed significantly reduced ability to bind cardiolipin, but retained its ability to stimulate procoagulant activity in monocytes. We found an explanation for this result by analyzing the structure of domain $V$ of $\beta 2$ GPI available in the PDB data bank (PDB ID 1C1Z, 1QUB, 3OP8 and 2KRI). The Lys308/Asn mutant, compared to other less potent Lys308 mutants (Lys308/Ala, Lys308/Gly and Lys308/Ser), is capable of forming a hydrogen bond with the sidechain of Lys282. In the Lys308/Asn mutant, this hydrogen bond combined with phospholipid-bound Leu313 restricts flexibility in the unstructured region between the residues 308 and 313 (Figure 6D). This unstructured region is stabilized by the binding of Lys308 and Leu313 to anionic phospholipids in wild type HA-DV. It is likely that the region between residues 308 and 313 is in the vicinity of the binding site for the receptor, because its flexibility affects the ability of HA-DV dimers to stimulate procoagulant activity in treated cells.

\section{Discussion}

We demonstrated that domain $\mathrm{V}$ of $\beta 2 \mathrm{GPI}$ ( $\beta 2 \mathrm{GPI}-\mathrm{DV}$ ) dimerized to mimic domain $\mathrm{V}$ in $\beta 2 \mathrm{GPI} /$ anti- $\beta 2 \mathrm{GPI}$ complexes is sufficient to induce procoagulant activity in PMA-differentiated U937 monocytic cells. Our data considerably simplify the search for the residues on $\beta 2 G P I$, which are involved in the upregulation of procoagulant activity by anti- $\beta 2$ GPI antibodies. The use of $\beta 2$ GPI-DV dimers instead of a full-length $\beta 2$ GPI can also simplify the search for receptors involved in the upregulation of procoagulant activity in monocytes by anti- $\beta 2 \mathrm{GPI}$ antibodies. This is a step towards understanding how $\beta 2 \mathrm{GPI} /$ anti- $\beta 2 \mathrm{GPI}$ complexes interact with receptors and, ultimately, towards a drug to treat anti- $\beta 2$ GPI-related thrombosis in APS.

Using site-directed mutagenesis, we changed individual residues in $\beta 2$ GPI-DV involved in the binding of $\beta 2 \mathrm{GPI}$ to ApoER2 and anionic phospholipids and compared the procoagulant activity induced by dimerized $\beta 2$ GPI-DV variants in treated U937 cells. It has been previously shown that domain $\mathrm{V}$ of $\beta 2 \mathrm{GPI}$ is important for stimulating platelet adhesion to collagen by dimeric $\beta 2 \mathrm{GPI}$ and that the increase of platelet adhesion is mediated by ApoER2 [33,55]. We did not find a correlation between the ability of a $\beta 2$ GPI-DV variant to stimulate procoagulant activity of monocytic cells and its ability to bind A1, which is the $\beta 2$ GPI-binding module from ApoER2. Our results suggest that binding to ApoER2 is not important for stimulating the procoagulant activity of monocytic cells by anti- $\beta 2$ GPI antibodies, highlighting the complexity of molecular mechanisms of thrombosis in antiphospholipid syndrome.

The surface area on $\beta 2$ GPI-DV involved in phospholipid binding is much larger than previously thought. Our data suggest that Lys308 actively participates in binding of $\beta 2$ GPI-DV to anionic phospholipids. When Lys308 was mutated to either Ser, Ala, Asn, Gly or Asp, cardiolipin binding was reduced to $37 \%, 32 \%, 28 \%, 21 \%$ and $9 \%$ of the level of wild type $\beta 2$ GPI-DV, respectively.

Our results show that the ability of mutants to come close to the cell membrane and attach to it, even moderately, is important for the stimulation of procoagulant activity. All active mutants in Group 1 in Figure 6C retained native residues in both phospholipid-binding loops, compared to inactive mutants in Group 2.

It has been previously shown that the binding of $\beta 2 \mathrm{GPI}$ to anionic phospholipids has two effects: (1) it causes conformational rearrangement of a full-length $\beta 2$ GPI to expose an epitope for anti- $\beta 2 \mathrm{GPI}$ antibodies otherwise hidden on $\beta 2$ GPI [56] and (2) creates local density of $\beta 2$ GPI to facilitate the formation of multivalent complexes with low affinity APS antibodies [57-59]. Using antibodies to an unobstructed HA-tag attached to $\beta 2 \mathrm{GPI}-\mathrm{DV}$, we have shown that the ability of $\beta 2 \mathrm{GPI}-\mathrm{DV}$ to reach the cell membrane and attach to it is important for signaling by $\beta 2 \mathrm{GPI} /$ anti- $\beta 2 \mathrm{GPI}$ complexes.

Our data suggest that the binding of $\beta 2$ GPI-DV to anionic phospholipids restricts the flexibility of the unstructured region in $\beta 2$ GPI-DV between the residues 308 and 313 influencing the ability of dimerized domain V of $\beta 2$ GPI to stimulate procoagulant activity in U937 cells. Stabilization of this region is achieved in wild type $\beta 2$ GPI-DV by anchoring Lys308 and Leu313 to a phospholipid 
membrane. In the Lys308/Asn mutant, which stimulates the procoagulant activity of cells similar to wild type $\beta 2 \mathrm{GPI}-\mathrm{DV}$, the unstructured region between the residues 308 and 313 is stabilized by a hydrogen bond constraining the Asn 308 residue and by phospholipid-bound Leu313. Since the flexibility of the stretch of residues between Lys308 and Leu313 influences the ability $\beta 2$ GPI-DV dimers to stimulate procoagulant activity, this region in $\beta 2 \mathrm{GPI}-\mathrm{DV}$ is likely close to the binding site for a cell-surface receptor.

Our results suggest a model in which $\beta 2$ GPI binds by its domain $V$ to anionic phospholipids on cellular surfaces, most likely to lipid rafts enriched in anionic phospholipids and signaling proteins [60]. The binding to anionic phospholipids restricts flexibility in the unstructured loop between phospholipid-bound residues Lys308 and Leu313 in $\beta 2$ GPI-DV, predisposing $\beta 2$ GPI-DV for binding to a receptor. Anti- $\beta 2 \mathrm{GPI}$ antibodies keep $\beta 2 \mathrm{GPI}$ attached to cellular membranes by increasing the avidity of $\beta 2 \mathrm{GPI} /$ antibody complexes for anionic phospholipids. Binding to a receptor occurs very close to the cellular surface, because $\beta 2$ GPI-DV has to be attached to anionic phospholipids in order to interact with a receptor (Figure 7). Whether the interaction of $\beta 2$ GPI-DV with cell-surface receptors leads directly to the stimulation of procoagulant activity in cells or facilitates the endocytosis of dimerized $\beta 2 \mathrm{GPI}-\mathrm{DV}$, which then signals from endosomes, awaits further investigation.

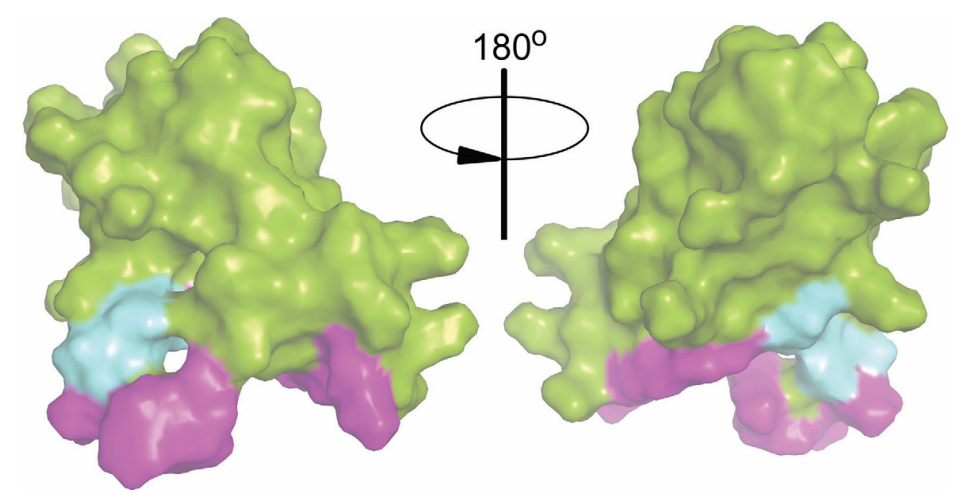

Figure 7. Surface representation of $\beta 2$ GPI-DV. The surface area around residues involved in binding to anionic phospholipids is colored magenta; the unstructured region between Lys308 and Leu313 is colored cyan.

The procoagulant activity induced in monocytes by anti- $\beta 2 \mathrm{GPI}$ antibodies depends on cell-surface TF. In isolated normal peripheral blood mononuclear cells (PBMC), anti- $\beta 2$ GPI antibodies significantly increased cell-surface TF activity and TF mRNA levels [42,61,62]. We have shown that cell-surface TF is a major contributor to the increased procoagulant activity of PMA-differentiated U937 monocytic cells treated with anti- $\beta 2$ GPI antibodies and $\beta 2$ GPI-DV dimers. The mechanism by which treatment with anti- $\beta 2$ GPI antibodies and $\beta 2$ GPI-DV dimers affects TF in U937 cells is not yet clear. We will continue investigating the extent to which treatment with anti- $\beta 2 \mathrm{GPI}$ antibodies contributes to de novo synthesis of TF versus decryption of TF already present on the cellular surface. Activation of cell-surface TF by anti- $\beta 2$ GPI antibodies and $\beta 2$ GPI-DV dimers could be accompanied by an increase in surface exposure of anionic phospholipids additionally contributing to procoagulant activity in the treated cells.

It is not yet clear what receptor in monocytes is responsible for the induction of procoagulant activity by anti- $\beta 2$ GPI antibodies and $\beta 2$ GPI-DV dimers. Experiments in PBMC implicate TLR2, TLR4 and TLR8 in the upregulation of TF by anti- $\beta 2$ GPI antibodies, which is accompanied by a TNF $\alpha$ release ranging from $0.4-10 \mathrm{ng} / \mathrm{mL}[26,42,44,63]$. TLR8 is a likely endosomal receptor for $\beta 2 \mathrm{GPI} /$ anti- $\beta 2 \mathrm{GPI}$ complexes [63]. It is also possible that endosomes have a not yet identified receptor contributing to monocyte activation by anti- $\beta 2$ GPI antibodies. We found that $\beta 2$ GPI/anti- $\beta 2$ GPI complexes, dimerized $\beta 2$ GPI-DV, LPS and Pam3CSK4 all induced procoagulant activity in PMA-differentiated U937 cells. However, $\beta 2 \mathrm{GPI} /$ anti- $\beta 2 \mathrm{GPI}$ complexes and dimerized $\beta 2 \mathrm{GPI}-\mathrm{DV}$ did not promote the release of TNF $\alpha$, 
in contrast to LPS and Pam3CSK4, which caused a massive release of TNF $\alpha$ into the cell culture medium. Our results suggest that another receptor, besides TLR4 and TLR2, can contribute to the upregulation of procoagulant activity in monocytes by $\beta 2 \mathrm{GPI} /$ antibody complexes and that the stimulation of this receptor does not lead to NF- $\mathrm{kB}$ activation. More investigation is required into the details of the signaling pathways induced by $\beta 2 \mathrm{GPI} /$ anti- $\beta 2 \mathrm{GPI}$ complexes and by dimers of $\beta 2 \mathrm{GPI}-\mathrm{DV}$ in PMA-differentiated U937 cells and how they compare to the signaling pathways induced in PBMC.

In conclusion, our studies in PMA-differentiated U937 monocytes have narrowed the location of the region on $\beta 2$ GPI responsible for the induction of procoagulant activity in monocytes by $\beta 2 \mathrm{GPI} /$ anti- $\beta 2 \mathrm{GPI}$ complexes down to domain V. Intact residues in $\beta 2 \mathrm{GPI}-\mathrm{DV}$ that bind to anionic phospholipids are important for the potentiation of procoagulant activity in monocytes. The binding site for a cell-surface receptor on $\beta 2$ GPI-DV is likely located in the vicinity of an unstructured region in $\beta 2$ GPI-DV between residues 308 and 313. The flexibility of this region, which is restricted in phospholipid-bound $\beta 2$ GPI-DV, affects the ability of dimerized $\beta 2$ GPI-DV to stimulate procoagulant activity on monocytes. Our data suggest that ApoER2 is not important for the potentiation of procoagulant activity in PMA-differentiated U937 cells. The identity of the receptor that plays a role in stimulating procoagulant activity in U937 cells and the signaling pathways initiated by $\beta 2 \mathrm{GPI} /$ anti- $\beta 2 \mathrm{GPI}$ complexes and $\beta 2 \mathrm{GPI}-\mathrm{DV}$ dimers awaits further investigation.

\section{Materials and Methods}

\subsection{Proteins}

A1 is a fragment of mouse ApoER2 (residues 12-47) in which Asp is substituted for Asn36. A1 was expressed in Escherichia coli and purified as previously described [64]. HA-DV consists of an HA tag (amino acid sequence YPYDVPDYA) added to the N-terminus of domain V of human $\beta 2 G P I$ (residues 244-326). HA-DV was subcloned into a pET15b vector (Novagen) in which the sequence recognized by the tobacco etch virus (TEV) protease was added after an N-terminal histidine tag so that the tag can be removed. The HA-DV protein and point mutants of HA-DV were expressed and purified as previously described [34].

\subsection{Cells and Culture Conditions}

The immortalized human monocyte U937 cells (ATCC, Manassas, VA, USA) were cultured in RPMI 1640 medium supplemented with 10\% fetal bovine serum (FBS) (Atlanta Biologicals, Flowery Branch, GA, USA), penicillin-streptomycin and L-glutamine (Gibco, ThermoFisher Scientific, Waltham, MA, USA) at $37{ }^{\circ} \mathrm{C}$ in a humidified atmosphere with $5 \% \mathrm{CO}_{2}$. Cells were seeded at a concentration of $5 \times 10^{5} \mathrm{~mL}^{-1}$ and treated for $72 \mathrm{~h}$ with $100 \mathrm{nM}$ phorbol 12-myristate 13-acetate (PMA) (Enzo Life Sciences, Farmingdale, NY, USA). After 72 h, nonadherent cells were removed along with the medium. A fresh medium containing 10\% FBS was added to the cells, and adherent cells were detached by gentle pipetting. Cells were pelleted and resuspended in RPMI medium. Differentiated U937 monocytes at a concentration of $1 \times 10^{6} \mathrm{~mL}^{-1}$ were incubated for $6 \mathrm{~h}$ at $37^{\circ} \mathrm{C}$ in a humidified atmosphere with $5 \% \mathrm{CO}_{2}$ in RPMI medium supplemented with $10 \%$ pooled normal human serum (Innovative Research, Novi, MI, USA) and test reagents as indicated. Human serum in cell culture media supplied $\beta 2$ GPI. When specified, cells were incubated in a serum free medium with or without purified $\beta 2$ GPI (Haematologic Technologies, Essex Junction, VT, USA), exchanged into a $20 \mathrm{mM}$ Hepes, $150 \mathrm{mM} \mathrm{NaCl}$, pH 7.5 buffer using a Zeba spin desalting column (ThermoFisher Scientific, Waltham, MA, USA) and added to the assay at a final concentration of $20 \mu \mathrm{g} / \mathrm{mL}$.

HA-DV and HA-DV mutants were used at an $8 \mu \mathrm{g} / \mathrm{mL}$ concentration measured by NanoDrop (ThermoScientific, Wilmington, DE, USA). The TLR2-specific ligand Pam3CSK4 was from InvivoGen, San Diego, CA, USA. Anti-HA antibody (Bethyl Laboratories, Montgomery, TX, USA) was exchanged into a $20 \mathrm{mM}$ Hepes, $150 \mathrm{mM} \mathrm{NaCl}$, pH 7.5 buffer using a Zeba spin desalting column to remove sodium azide. Goat anti- $\beta 2$ GPI (CL2001AP, Cedarlane Laboratories, Burlington, NC, USA) was raised 
against human $\beta 2$ GPI and affinity purified on immobilized $\beta 2$ GPI. LPS from Salmonella enterica (Sigma, St. Louis, MO, USA) was used as a positive control. Endotoxin levels in test reagents were measured with the Limulus Amebocyte Lysate (LAL) chromogenic endotoxin quantification kit (ThermoFisher Scientific, Waltham, MA, USA) at concentrations used in the assays. Endotoxin levels in HA-DV and all HA-DV mutants were below the detection limit of $0.1 \mathrm{EUmL}^{-1}$, except for Lys286/Glu-Lys287/Glu and Lys286/Asn-Lys287/Asn, for which measured endotoxin was 0.5 EUmL ${ }^{-1}$. Endotoxin levels in $\beta 2 \mathrm{GPI}$, anti- $\beta 2 \mathrm{GPI}$ and anti-HA were $0.15,0.25$ and $0.6 \mathrm{EUmL}^{-1}$, respectively. Endotoxin in test reagents was far below $1.5 \mathrm{EUmL}^{-1}$, which corresponds to $1 \mathrm{ng} / \mathrm{mL}$ of LPS from Salmonella enterica. This amount of LPS did not have a statistically significant effect on U937 cells.

\subsection{Measurements of the Procoagulant Activity of U937 Cells}

After incubating for $6 \mathrm{~h}$ with test reagents, cells were pelleted, washed with RPMI and counted, and their viability, which was at least $90 \%$ in reported experiments, was assessed by Trypan Blue (ThermoFisher Scientific, Waltham, MA, USA). The procoagulant activity expressed by cells was quantified by measuring clotting kinetics in pooled normal platelet-poor human plasma anticoagulated with sodium citrate (Innovative Research, Novi, MI, USA). When specified, plasma depleted of factors VII, XI or XII (Haematologic Technologies, Essex Junction, VT, USA) was used in clotting studies. Clotting kinetics were measured at $37^{\circ} \mathrm{C}$ using 96-well ELISA plates and a Spectramax 340PC Microplate Reader (Molecular Devices Inc., Sunnyvale, CA, USA). Human plasma, $50 \mu L$, was added to $50 \mu \mathrm{L}$ of cells $\left(2 \times 10^{6} \mathrm{~mL}^{-1}\right)$ suspended in serum-free RPMI. The mixture was incubated for $3 \mathrm{~min}$ at $37^{\circ} \mathrm{C}$, and coagulation was initiated by adding $50 \mu \mathrm{L}$ of $40 \mathrm{mM} \mathrm{CaCl}$ in $20 \mathrm{mM}$ Hepes, $150 \mathrm{mM}$ $\mathrm{NaCl}$ buffer, $\mathrm{pH}$ 7.5. Clotting kinetics were recorded by measuring absorbance at $405 \mathrm{~nm}$. Kinetics data were fitted to a 4-parameter equation using the Gnuplot 5.0 program (http://www.gnuplot.info/). The time needed to achieve a half-maximal increase in OD was calculated for each kinetics curve and used to characterize the procoagulant activity of the cells.

\subsection{TNF $\alpha$ ELISA}

After $6 \mathrm{~h}$ of stimulation with test reagents, cells were pelleted, and the supernatant was collected and stored frozen at $-80{ }^{\circ} \mathrm{C}$ until use. The concentration of TNF $\alpha$ released into media was quantified with Quantikine ELISA (R\&D Systems, Minneapolis, MN, USA).

\subsection{Isothermal Titration Calorimetry}

To measure the binding between A1 and the HA-tagged domain V of $\beta 2$ GPI (HA-DV) and its variants, lyophilized proteins were resuspended in a $25 \mathrm{mM}$ Hepes, pH 7.1 buffer containing $50 \mathrm{mM}$ $\mathrm{NaCl}$ and $2 \mathrm{mM} \mathrm{CaCl}_{2}$ and dialyzed overnight at $4{ }^{\circ} \mathrm{C}$ in the same buffer. Measurements were performed at $298 \mathrm{~K}$ using a MicroCal iTC200 system (Malvern, Malvern Instruments, U.K.). A1 at a concentration of $500 \mu \mathrm{M}$ was placed into an injection syringe and titrated in $2 \mu \mathrm{L}$ increments into a sample cell containing $50 \mu \mathrm{M}$ of HA-DV or HA-DV variants. Binding isotherms were fit to a one site binding model using the Origin software for ITC.

\subsection{Cardiolipin ELISA}

ELISA 96-well plates (Costar, Corning, NY, USA) were coated with $50 \mu \mathrm{L}$ per well of cardiolipin (Sigma, St. Louis, MO, USA) prepared at $200 \mu \mathrm{g} / \mathrm{mL}$ in ethanol and blocked for $2 \mathrm{~h}$ with $4 \%$ BSA in a $20 \mathrm{mM}$ Tris, $100 \mathrm{mM} \mathrm{NaCl}$ buffer at $\mathrm{pH}$ 7.4. To generate a binding curve, increasing concentrations of HA-DV were applied to wells. The binding data were fit to a one-site model using the Gnuplot 5.0 program (http://www.gnuplot.info/). Cardiolipin binding by HA-DV variants was compared to cardiolipin binding by HA-DV at protein concentrations of $500 \mathrm{nM}$ and $1000 \mathrm{nM}$. Bound HA-tagged proteins were detected with HRP-conjugated anti-HA-tag antibody (ab1265, Abcam, Cambridge, MA, USA) using a TMB (3,3',5,5'-tetramethylbenzidine) substrate. Absorbances at $450 \mathrm{~nm}$ were measured on a Spectramax 340PC Microplate Reader (Molecular Devices Inc., Sunnyvale, CA, USA). 


\subsection{Statistical Analysis}

Results are presented as the mean \pm standard deviation calculated from at least three independent experiments. Statistical significance was evaluated with STATA statistical software (College Station, TX, USA) using one-way ANOVA with Bonferroni correction for multiple comparisons.

Acknowledgments: This work was supported by the R01 HL096693 grant from the National Institute of Health to N. Beglova. Salary support for D. A. Barrios was from NIH Fellowship Training Program T32 HL007917.

Author Contributions: A.K. and N.B. designed the experiments. A.K. and D.A.B. performed the experiments. A.K., D.A.B. and N.B. analyzed the data. N.B. devised the studies and wrote the paper.

Conflicts of Interest: The authors declare no conflict of interest.

\section{References}

1. Bertolaccini, M.L.; Amengual, O.; Andreoli, L.; Atsumi, T.; Chighizola, C.B.; Forastiero, R.; de Groot, P.; Lakos, G.; Lambert, M.; Meroni, P.; et al. 14th international congress on antiphospholipid antibodies task force. Report on antiphospholipid syndrome laboratory diagnostics and trends. Autoimmun. Rev. 2014, 13, 917-930. [CrossRef] [PubMed]

2. Miyakis, S.; Lockshin, M.D.; Atsumi, T.; Branch, D.W.; Brey, R.L.; Cervera, R.; Derksen, R.H.; de Groot, P.G.; Koike, T.; Meroni, P.L.; et al. International consensus statement on an update of the classification criteria for definite antiphospholipid syndrome (APS). J. Thromb. Haemost. 2006, 4, 295-306. [CrossRef] [PubMed]

3. Giles, I.P.; Isenberg, D.A.; Latchman, D.S.; Rahman, A. How do antiphospholipid antibodies bind beta2-glycoprotein I? Arthritis Rheum. 2003, 48, 2111-2121. [CrossRef] [PubMed]

4. Lieby, P.; Soley, A.; Levallois, H.; Hugel, B.; Freyssinet, J.M.; Cerutti, M.; Pasquali, J.L.; Martin, T. The clonal analysis of anticardiolipin antibodies in a single patient with primary antiphospholipid syndrome reveals an extreme antibody heterogeneity. Blood 2001, 97, 3820-3828. [CrossRef] [PubMed]

5. Sorice, M.; Pittoni, V.; Griggi, T.; Losardo, A.; Leri, O.; Magno, M.S.; Misasi, R.; Valesini, G. Specificity of anti-phospholipid antibodies in infectious mononucleosis: A role for anti-cofactor protein antibodies. Clin. Exp. Immunol. 2000, 120, 301-306. [CrossRef] [PubMed]

6. Wolf, P.; Gretler, J.; Aglas, F.; Auer-Grumbach, P.; Rainer, F. Anticardiolipin antibodies in rheumatoid arthritis: Their relation to rheumatoid nodules and cutaneous vascular manifestations. Br. J. Dermatol. 1994, 131, 48-51. [CrossRef] [PubMed]

7. Forastiero, R.R.; Martinuzzo, M.E.; Kordich, L.C.; Carreras, L.O. Reactivity to beta 2 glycoprotein I clearly differentiates anticardiolipin antibodies from antiphospholipid syndrome and syphilis. Thromb. Haemost. 1996, 75, 717-720. [PubMed]

8. Manukyan, D.; Muller-Calleja, N.; Jackel, S.; Luchmann, K.; Monnikes, R.; Kiouptsi, K.; Reinhardt, C.; Jurk, K.; Walter, U.; Lackner, K.J. Cofactor-independent human antiphospholipid antibodies induce venous thrombosis in mice. J. Thromb. Haemost. 2016, 14, 1011-1020. [CrossRef] [PubMed]

9. Merashli, M.; Noureldine, M.H.; Uthman, I.; Khamashta, M. Antiphospholipid syndrome: An update. Eur. J. Clin. Investig. 2015, 45, 653-662. [CrossRef] [PubMed]

10. Giannakopoulos, B.; Krilis, S.A. The pathogenesis of the antiphospholipid syndrome. N. Engl. J. Med. 2013, 368, 1033-1044. [CrossRef] [PubMed]

11. Meroni, P.L.; Chighizola, C.B.; Rovelli, F.; Gerosa, M. Antiphospholipid syndrome in 2014: More clinical manifestations, novel pathogenic players and emerging biomarkers. Arthritis Res. Ther. 2014, 16, 209. [CrossRef] [PubMed]

12. Lopez, L.R.; Dier, K.J.; Lopez, D.; Merrill, J.T.; Fink, C.A. Anti-beta 2-glycoprotein I and antiphosphatidylserine antibodies are predictors of arterial thrombosis in patients with antiphospholipid syndrome. Am. J. Clin. Pathol. 2004, 121, 142-149. [CrossRef] [PubMed]

13. Day, H.M.; Thiagarajan, P.; Ahn, C.; Reveille, J.D.; Tinker, K.F; Arnett, F.C. Autoantibodies to beta2-glycoprotein I in systemic lupus erythematosus and primary antiphospholipid antibody syndrome: Clinical correlations in comparison with other antiphospholipid antibody tests. J. Rheumatol. 1998, 25, 667-674. [PubMed] 
14. Cabiedes, J.; Cabral, A.R.; Alarcon-Segovia, D. Clinical manifestations of the antiphospholipid syndrome in patients with systemic lupus erythematosus associate more strongly with anti-beta 2-glycoprotein-I than with antiphospholipid antibodies. J. Rheumatol. 1995, 22, 1899-1906. [PubMed]

15. De Laat, B.; Pengo, V.; Pabinger, I.; Musial, J.; Voskuyl, A.E.; Bultink, I.E.; Ruffatti, A.; Rozman, B.; Kveder, T.; de Moerloose, P.; et al. The association between circulating antibodies against domain i of beta2-glycoprotein I and thrombosis: An international multicenter study. J. Thromb. Haemost. 2009, 7, 1767-1773. [CrossRef] [PubMed]

16. Zhang, S.; Wu, Z.; Chen, S.; Li, J.; Wen, X.; Li, L.; Zhang, W.; Zhao, J.; Zhang, F.; Li, Y. Evaluation of the diagnostic potential of antibodies to beta2-glycoprotein I domain I in chinese patients with antiphospholipid syndrome. Sci. Rep. 2016, 6, 23839. [CrossRef] [PubMed]

17. De Laat, H.B.; Derksen, R.H.; Urbanus, R.T.; Roest, M.; de Groot, P.G. Beta2-glycoprotein I-dependent lupus anticoagulant highly correlates with thrombosis in the antiphospholipid syndrome. Blood 2004, 104, 3598-3602. [CrossRef] [PubMed]

18. Willis, R.; Pierangeli, S.S. Anti-beta2-glycoprotein I antibodies. Ann. N. Y. Acad. Sci. 2013, 1285, 44-58. [CrossRef] [PubMed]

19. Arad, A.; Proulle, V.; Furie, R.A.; Furie, B.C.; Furie, B. Beta(2)-glycoprotein-I autoantibodies from patients with antiphospholipid syndrome are sufficient to potentiate arterial thrombus formation in a mouse model. Blood 2011, 117, 3453-3459. [CrossRef] [PubMed]

20. Jankowski, M.; Vreys, I.; Wittevrongel, C.; Boon, D.; Vermylen, J.; Hoylaerts, M.F.; Arnout, J. Thrombogenicity of beta 2-glycoprotein I-dependent antiphospholipid antibodies in a photochemically induced thrombosis model in the hamster. Blood 2003, 101, 157-162. [CrossRef] [PubMed]

21. De Groot, P.G.; Urbanus, R.T. The significance of auto-antibodies against beta2-glycoprotein I. Blood 2012, 120, 266-274. [CrossRef] [PubMed]

22. Pierangeli, S.S.; Vega-Ostertag, M.E.; Raschi, E.; Liu, X.; Romay-Penabad, Z.; De Micheli, V.; Galli, M.; Moia, M.; Tincani, A.; Borghi, M.O.; et al. Toll-like receptor and antiphospholipid mediated thrombosis: In vivo studies. Ann. Rheum. Dis. 2007, 66, 1327-1333. [CrossRef] [PubMed]

23. Romay-Penabad, Z.; Aguilar-Valenzuela, R.; Urbanus, R.T.; Derksen, R.H.; Pennings, M.T.; Papalardo, E.; Shilagard, T.; Vargas, G.; Hwang, Y.; de Groot, P.G.; et al. Apolipoprotein E receptor 2 is involved in the thrombotic complications in a murine model of the antiphospholipid syndrome. Blood 2011, 117, 1408-1414. [CrossRef] [PubMed]

24. Romay-Penabad, Z.; Montiel-Manzano, M.G.; Shilagard, T.; Papalardo, E.; Vargas, G.; Deora, A.B.; Wang, M.; Jacovina, A.T.; Garcia-Latorre, E.; Reyes-Maldonado, E.; et al. Annexin A2 is involved in antiphospholipid antibody-mediated pathogenic effects in vitro and in vivo. Blood 2009, 114, 3074-3083. [CrossRef] [PubMed]

25. Laplante, P.; Fuentes, R.; Salem, D.; Subang, R.; Gillis, M.A.; Hachem, A.; Farhat, N.; Qureshi, S.T.; Fletcher, C.A.; Roubey, R.A.; et al. Antiphospholipid antibody-mediated effects in an arterial model of thrombosis are dependent on toll-like receptor 4. Lupus 2016, 25, 162-176. [CrossRef] [PubMed]

26. Brandt, K.J.; Fickentscher, C.; Boehlen, F.; Kruithof, E.K.; de Moerloose, P. NF-kappab is activated from endosomal compartments in antiphospholipid antibodies-treated human monocytes. J. Thromb. Haemost. 2014, 12, 779-791. [CrossRef] [PubMed]

27. De Groot, P.G.; Meijers, J.C. Beta(2)-glycoprotein I: Evolution, structure and function. J. Thromb. Haemost. 2011, 9, 1275-1284. [CrossRef] [PubMed]

28. Meroni, P.L. Anti-beta-2 glycoprotein I epitope specificity: From experimental models to diagnostic tools. Lupus 2016, 25, 905-910. [CrossRef] [PubMed]

29. Hunt, J.; Krilis, S. The fifth domain of beta 2-glycoprotein I contains a phospholipid binding site (cys281-cys288) and a region recognized by anticardiolipin antibodies. J. Immunol. 1994, 152, 653-659. [PubMed]

30. Mehdi, H.; Naqvi, A.; Kamboh, M.I. A hydrophobic sequence at position 313-316 (Leu-Ala-Phe-Trp) in the fifth domain of apolipoprotein H (beta2-glycoprotein I) is crucial for cardiolipin binding. Eur. J. Biochem. 2000, 267, 1770-1776. [CrossRef] [PubMed]

31. Pennings, M.T.; Derksen, R.H.; van Lummel, M.; Adelmeijer, J.; VanHoorelbeke, K.; Urbanus, R.T.; Lisman, T.; de Groot, P.G. Platelet adhesion to dimeric beta-glycoprotein I under conditions of flow is mediated by at least two receptors: Glycoprotein Ibalpha and apolipoprotein E receptor 2'. J. Thromb. Haemost. 2007, 5, 369-377. [CrossRef] [PubMed] 
32. Sheng, Y.; Sali, A.; Herzog, H.; Lahnstein, J.; Krilis, S.A. Site-directed mutagenesis of recombinant human beta 2-glycoprotein I identifies a cluster of lysine residues that are critical for phospholipid binding and anti-cardiolipin antibody activity. J. Immunol. 1996, 157, 3744-3751. [PubMed]

33. Van Lummel, M.; Pennings, M.T.; Derksen, R.H.; Urbanus, R.T.; Lutters, B.C.; Kaldenhoven, N.; de Groot, P.G. The binding site in \{beta\}2-glycoprotein I for ApoER2' on platelets is located in domain V. J. Biol. Chem. 2005, 280, 36729-36736. [CrossRef] [PubMed]

34. Lee, C.J.; De Biasio, A.; Beglova, N. Mode of interaction between beta2GPI and lipoprotein receptors suggests mutually exclusive binding of beta2GPI to the receptors and anionic phospholipids. Structure 2010, 18, 366-376. [CrossRef] [PubMed]

35. Amengual, O.; Atsumi, T.; Khamashta, M.A. Tissue factor in antiphospholipid syndrome: Shifting the focus from coagulation to endothelium. Rheumatol. Oxf. 2003, 42, 1029-1031. [CrossRef] [PubMed]

36. Kinev, A.V.; Roubey, R.A. Tissue factor in the antiphospholipid syndrome. Lupus 2008, 17, 952-958. [CrossRef] [PubMed]

37. Boles, J.; Mackman, N. Role of tissue factor in thrombosis in antiphospholipid antibody syndrome. Lupus 2010, 19, 370-378. [CrossRef] [PubMed]

38. Cuadrado, M.J.; Lopez-Pedrera, C.; Khamashta, M.A.; Camps, M.T.; Tinahones, F.; Torres, A.; Hughes, G.R.; Velasco, F. Thrombosis in primary antiphospholipid syndrome: A pivotal role for monocyte tissue factor expression. Arthritis. Rheum. 1997, 40, 834-841. [CrossRef] [PubMed]

39. Dobado-Berrios, P.M.; Lopez-Pedrera, C.; Velasco, F.; Aguirre, M.A.; Torres, A.; Cuadrado, M.J. Increased levels of tissue factor mrna in mononuclear blood cells of patients with primary antiphospholipid syndrome. Thromb. Haemost. 1999, 82, 1578-1582. [PubMed]

40. Nojima, J.; Masuda, Y.; Iwatani, Y.; Suehisa, E.; Futsukaichi, Y.; Kuratsune, H.; Watanabe, Y.; Takano, T.; Hidaka, Y.; Kanakura, Y. Tissue factor expression on monocytes induced by anti-phospholipid antibodies as a strong risk factor for thromboembolic complications in sle patients. Biochem. Biophys. Res. Commun. 2008, 365, 195-200. [CrossRef] [PubMed]

41. Lambrianides, A.; Carroll, C.J.; Pierangeli, S.S.; Pericleous, C.; Branch, W.; Rice, J.; Latchman, D.S.; Townsend, P.; Isenberg, D.A.; Rahman, A.; et al. Effects of polyclonal IgG derived from patients with different clinical types of the antiphospholipid syndrome on monocyte signaling pathways. J. Immunol. 2010, 184, 6622-6628. [CrossRef] [PubMed]

42. Satta, N.; Kruithof, E.K.; Fickentscher, C.; Dunoyer-Geindre, S.; Boehlen, F.; Reber, G.; Burger, D.; de Moerloose, P. Toll-like receptor 2 mediates the activation of human monocytes and endothelial cells by antiphospholipid antibodies. Blood 2011, 117, 5523-5531. [CrossRef] [PubMed]

43. Xie, H.; Zhou, H.; Wang, H.; Chen, D.; Xia, L.; Wang, T.; Yan, J. Anti-beta(2)GPI/beta(2)GPI induced TF and TNF-alpha expression in monocytes involving both TLR4/MYD88 and TLR4/TRIF signaling pathways. Mol. Immunol. 2013, 53, 246-254. [CrossRef] [PubMed]

44. Sorice, M.; Longo, A.; Capozzi, A.; Garofalo, T.; Misasi, R.; Alessandri, C.; Conti, F.; Buttari, B.; Rigano, R.; Ortona, E.; et al. Anti-beta2-glycoprotein I antibodies induce monocyte release of tumor necrosis factor alpha and tissue factor by signal transduction pathways involving lipid rafts. Arthritis. Rheum. 2007, 56, 2687-2697. [CrossRef] [PubMed]

45. Bazzan, M.; Vaccarino, A.; Stella, S.; Bertero, M.T.; Carignola, R.; Montaruli, B.; Roccatello, D.; Shoenfeld, Y.; Piedmont, A.P.S.C. Thrombotic recurrences and bleeding events in APS vascular patients: A review from the literature and a comparison with the APS piedmont cohort. Autoimmun. Rev. 2013, 12, 826-831. [CrossRef] [PubMed]

46. Cervera, R.; Serrano, R.; Pons-Estel, G.J.; Ceberio-Hualde, L.; Shoenfeld, Y.; de Ramon, E.; Buonaiuto, V.; Jacobsen, S.; Zeher, M.M.; Tarr, T.; et al. Morbidity and mortality in the antiphospholipid syndrome during a 10-year period: A multicentre prospective study of 1000 patients. Ann. Rheum. Dis. 2015, 74, 1011-1018. [CrossRef] [PubMed]

47. Chighizola, C.B.; Ubiali, T.; Meroni, P.L. Treatment of thrombotic antiphospholipid syndrome: The rationale of current management-an insight into future approaches. J. Immun. Res. 2015, 2015, 951424. [CrossRef] [PubMed]

48. Pedrinaci, S.; Ruiz-Cabello, F.; Gomez, O.; Collado, A.; Garrido, F. Protein kinase c-mediated regulation of the expression of CD14 and CD11/CD18 in U937 cells. Int. J. Cancer 1990, 45, 294-298. [CrossRef] [PubMed] 
49. Fan, X.; Krahling, S.; Smith, D.; Williamson, P.; Schlegel, R.A. Macrophage surface expression of annexins I and II in the phagocytosis of apoptotic lymphocytes. Mol. Biol. Cell 2004, 15, 2863-2872. [CrossRef] [PubMed]

50. Greene, C.M.; McElvaney, N.G.; O’Neill, S.J.; Taggart, C.C. Secretory leucoprotease inhibitor impairs toll-like receptor 2- and 4-mediated responses in monocytic cells. Infect. Immun. 2004, 72, 3684-3687. [CrossRef] [PubMed]

51. Okamoto, M.; Hirai, H.; Taniguchi, K.; Shimura, K.; Inaba, T.; Shimazaki, C.; Taniwaki, M.; Imanishi, J. Toll-like receptors (TLRs) are expressed by myeloid leukaemia cell lines, but fail to trigger differentiation in response to the respective TLR ligands. Br. J. Haematol. 2009, 147, 585-587. [CrossRef] [PubMed]

52. Yang, X.V.; Banerjee, Y.; Fernandez, J.A.; Deguchi, H.; Xu, X.; Mosnier, L.O.; Urbanus, R.T.; de Groot, P.G.; White-Adams, T.C.; McCarty, O.J.; et al. Activated protein C ligation of ApoER2 (Lrp8) causes DAB1-dependent signaling in U937 cells. Proc. Natl. Acad. Sci. USA 2009, 106, 274-279. [CrossRef] [PubMed]

53. Kolyada, A.; Karageorgos, I.; Mahlawat, P.; Beglova, N. An A1-A1 mutant with improved binding and inhibition of beta2GPI/antibody complexes in antiphospholipid syndrome. FEBS J. 2015, 282, 864-873. [CrossRef] [PubMed]

54. Pennings, M.T.; Derksen, R.H.; Urbanus, R.T.; Tekelenburg, W.L.; Hemrika, W.; de Groot, P.G. Platelets express three different splice variants of ApoER2 that are all involved in signaling. J. Thromb. Haemost. 2007, 5, 1538-1544. [CrossRef] [PubMed]

55. Urbanus, R.T.; Pennings, M.T.; Derksen, R.H.; de Groot, P.G. Platelet activation by dimeric beta(2)-glycoprotein I requires signaling via both glycoprotein Ibalpha and apolipoprotein E receptor $2^{\prime}$. J. Thromb. Haemost. 2008, 6, 1405-1412. [CrossRef] [PubMed]

56. Agar, C.; van Os, G.M.; Morgelin, M.; Sprenger, R.R.; Marquart, J.A.; Urbanus, R.T.; Derksen, R.H.; Meijers, J.C.; de Groot, P.G. \{beta\}2-glycoprotein I can exist in two conformations: Implications for our understanding of the antiphospholipid syndrome. Blood 2010, 116, 1336-1343. [CrossRef] [PubMed]

57. Roubey, R.A.; Eisenberg, R.A.; Harper, M.F.; Winfield, J.B. “Anticardiolipin” autoantibodies recognize beta 2-glycoprotein I in the absence of phospholipid. Importance of Ag density and bivalent binding. J. Immunol. 1995, 154, 954-960. [PubMed]

58. Tincani, A.; Spatola, L.; Prati, E.; Allegri, F.; Ferremi, P.; Cattaneo, R.; Meroni, P.; Balestrieri, G. The anti-beta2-glycoprotein I activity in human anti-phospholipid syndrome sera is due to monoreactive low-affinity autoantibodies directed to epitopes located on native beta2-glycoprotein I and preserved during species' evolution. J. Immunol. 1996, 157, 5732-5738. [PubMed]

59. Willems, G.M.; Janssen, M.P.; Pelsers, M.M.; Comfurius, P.; Galli, M.; Zwaal, R.F.; Bevers, E.M. Role of divalency in the high-affinity binding of anticardiolipin antibody-beta 2-glycoprotein I complexes to lipid membranes. Biochemistry 1996, 35, 13833-13842. [CrossRef] [PubMed]

60. Pike, L.J. The challenge of lipid rafts. J. Lipid Res. 2009, 50, S323-S328. [CrossRef] [PubMed]

61. Lopez-Pedrera, C.; Buendia, P.; Cuadrado, M.J.; Siendones, E.; Aguirre, M.A.; Barbarroja, N.; Montiel-Duarte, C.; Torres, A.; Khamashta, M.; Velasco, F. Antiphospholipid antibodies from patients with the antiphospholipid syndrome induce monocyte tissue factor expression through the simultaneous activation of NF-kappab/Rel proteins via the p38 mitogen-activated protein kinase pathway, and of the MEK-1/ERK pathway. Arthritis. Rheum. 2006, 54, 301-311. [PubMed]

62. Zhou, H.; Wolberg, A.S.; Roubey, R.A. Characterization of monocyte tissue factor activity induced by IgG antiphospholipid antibodies and inhibition by dilazep. Blood 2004, 104, 2353-2358. [CrossRef] [PubMed]

63. Doring, Y.; Hurst, J.; Lorenz, M.; Prinz, N.; Clemens, N.; Drechsler, M.D.; Bauer, S.; Chapman, J.; Shoenfeld, Y.; Blank, M.; et al. Human antiphospholipid antibodies induce TNFalpha in monocytes via toll-like receptor 8. Immunobiology 2010, 215, 230-241. [CrossRef] [PubMed]

64. Kolyada, A.; Lee, C.J.; De Biasio, A.; Beglova, N. A novel dimeric inhibitor targeting beta2GPI in beta2GPI/antibody complexes implicated in antiphospholipid syndrome. PLOS ONE 2010, 5, e15345. [CrossRef] [PubMed]

(C) 2017 by the authors. Licensee MDPI, Basel, Switzerland. This article is an open access article distributed under the terms and conditions of the Creative Commons Attribution (CC BY) license (http:/ / creativecommons.org/licenses/by/4.0/). 